り阪神大震災での被害状況の説明があった，その中で， アンカボルト固定を行っていない制御ユニットの転倒被 害が多かったこと，アンカボルト固定してあった TV 装 置には大きな被害が少なかったことが報告された，以下 の項目について審議がなされた。

○適用範囲

○参考文献，資料の選定

○設計震度の決定

○アンカボルトの強度基準

設置面の指定

○非固定機器の取扱

○耐震設置指針との関連（JIRA サイド設備設計標準化 委員会との連携)

設計用基準震度の審議では，今回参考とした文献では， 設計用基準震度は0.3 (300 Gal) としているが，これは阪 神大震災の前に発行された值であるため, 基準震度を $0.3(300 \mathrm{Gal})$ 震度 6 相当加 $50.4(400 \mathrm{Gal})$ 震度 7 相当 にすることとした。これについてユーザ側より医用機器 の重要度，患者の安全性を考えると設計震度を決める各 種係数はできるだけ大きい值を採用すべき，直下型地震 を考えると $400 \mathrm{Gal} て ゙ も$ 不足ではないかとの意見もださ れたが，各種係数にはそれぞれに安全率が含まれており， 最大値の掛け算では過剩傾向になる，また，基準震度に 関しては世の中の基準値を見直し今後の参考とすること とした。

日本放射線機器工業会では，平成 $8 \sim 10$ 年度の事業と して耐震設計指針を取り上げ外部専門家にも参加を要請 し作成委員会を構成する予定で, 本 SC-2102 委員会は設 置標準化委員会とともに分科会として位置付けられる予 定である．したがって，現在審議中の指針を「中間報告」 として，本年度中に審議を終了する予定である。

（上遠野昭）

\section{$4.4 \mathrm{X}$ 線装置周辺機器映像装置班}

今年度は，SC3204（X線用 I.I）の委員会が1度開かれ たのみである。会議の内容は, IEC 62B/250/DIS (Draft IEC 1267-7，X線 I.Iの「MTF の決定」）文書審議であ った。ドラフトからは，MTF 测定には CCDを用い，光 電子増倍管については削除された。この点について論議 した結果，その理由が明確でないということで，この案 反対と決まった，但し，以下の条件が満たされる場合に は賛成することとした，(1)光電子増倍管を復活する，(2) 測定における，スリットの長さを10 mm にする。(3)測定 における距離についての規定を設けない。

今後, ドラフトの議决とは別に, 各社持ち回り測定し たデー夕に違いがあることから，測定における正確さを 期したうえ, 再度, 光電子増倍管による测定を行うこと とした。

また，IEC 1262-1〜6のスタンダードが決定したこと
を受けて，JISのないDQEについて，JIS 化の作業を開 始することになった。まずは, JESRA 化を行うこととし た。また，MTF の測定時に，DQEの測定を合わせて行 うことになった。

(篠原文章)

\section{$4.5 \mathrm{X}$ 線 CT 班}

本年度も委員会は，ほほ月 1 回の割合で開催された。 主な活動内容は，以下の通りである。

IEC SC 62B WG25「X線 CT 装置」の審議,

IEC 1223-2-6 Constancy tests「X線 C'T装置の恒常 性試験規格」の和訳作業,

CT 規格案（工業会規格）の審議を行なった。

1. IEC 62B WG25「X線 CT装置」の審議（WG25： Safety of $X$-ray equipment for computed tomogra. phy)

昨年, IEC 内に「X線 CT 装置」の規格化について WG が発足し，日本側としても委員を送り審議に参加した。 昨年は，8月にドイツにて第1回の会議が開催され，12 月に第 2 回が開催された。今年は 9 月に開催されたが出 席できなかった。これまでの内容としては，

（1）ヘリカルも含めた規格なのか，検討を要する。へ リカルの場合，曝射時間超過についてどう対応するか検

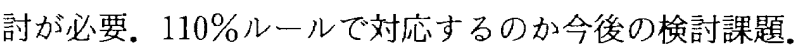

(2) 天板のアルミ当量は, 個別規格としては不要で IEC 601-1-3 に従えばよい，FDA では除外している。

(3) Dose profile, Sensitivity profile の定義は FDA, IEC の不変性試験に合わせる。

(4) Dose profile は, $2 \mathrm{~mm}$ 以上で公称スライス厚の 30 \%または $50 \%$ とし $1 \mathrm{~mm}$ スライスについては規定しな い，今後 WGで議論を要する。

(5) CTDI に CTDI 100 が提案されたが，2つの值がで まわるとユーザーに混乱をまねき，メ一カー側にも負担 増しとなる．CTDI だけにすべきと今後提案していく。

2. IEC 1223-2-6 Constancy tests $\ulcorner\mathrm{X}$ 線 CT 装置の不 変性試験規格」の和訳作業

IECよりX線 CT 装置の不変性試験規格が発行され 阼年度より和訳作業を行ってきた。今年度ほほ作業は終 了し，JESRA 規格として発行される予定である。

（規格番号は，JESRA EJ0021）

3. CT 装置規格案（工業会規格：JESRA）の審議 昨年度からの継続審議となっていたが，WG25の審議 および不変性試験の和訳作業のため審議が遅れている。 早急に規格化に向け作業をすすめる予定である.

（北村善明）

\subsection{MR 班}

4.6.1 MR 標準化

この班は，ほほ月 1 回の割で会議を開いてきた。今年 度の事業計画は， 